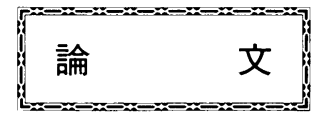

\title{
イチジクの熟成と日射量の関係に関する統計的考察
}

\author{
専門会員 門 永 鉄 雄 専門会員 向 阪 信 - 正会員 柳 原 等 \\ (松下電工株式会社) （中部電力株式会社）
}

\section{Statistical Consideration of Relationship between Solar Radiant Quantity and Fig Maturation}

Fellow Member Tetsuo Kadonaga, Fellow Member Shinichi Kohsaka (Matsushita Electric Works, Ltd.) and Member Hitoshi Yanagihara (Chubu Electric Power Co., Inc.)

\begin{abstract}
Japan does not receive enough solar energy to grow figs. By comparing the received solar energy of major fig producing areas of the world and Japan, we have derived the supplemental light energy value, which is the minimum additional light energy necessary for optimal fig maturation. By supplementing natural sunlight with this optimum value by electrical lighting, the fig season in Japan can be lengthened, crop volume increased, and fruit quality improved.

The optimum period for fig maturation in Nagoya is from June to September, when the minimum temperature remains above $20{ }^{\circ} \mathrm{C}$ in Nagoya, Athens, Izmir, and San Diego. During this same period, however, Athens receives direct sunlight for approximately 1,308 hours, while Nagoya gets approximately 638 hours, i. e. about $49 \%$ of Athens. These four months also provide average estimated solar energy levels of $17.5 \mathrm{MJ} \cdot \mathrm{m}^{-2} \cdot \mathrm{day}^{-1}$ for Athens, $15.3 \mathrm{MJ} \cdot \mathrm{m}^{-2} \cdot \mathrm{day}^{-1}$ for San Diego, and 8.8 $\mathrm{MJ} \cdot \mathrm{m}^{-2} \cdot \mathrm{day}^{-1}$ for Nagoya. A normal cultivation environment from January to March in winter will require additional supplemental light energy $5.1 \mathrm{MJ} \cdot \mathrm{m}^{-2} \cdot$ day $^{-1}$ which is derived from the difference in the solar energy between $8.8 \mathrm{MJ} \cdot \mathrm{m}^{-2}$. day $^{-1}$ for outdoor maturation in Nagoya and $3.7 \mathrm{MJ} \cdot \mathrm{m}^{-2} \cdot \mathrm{day}^{-1}$ for a green house in winter.
\end{abstract}

KEYWORDS : fig, maturation, coloring, daylight-hours, solar radiant energy, solar irradiance, supplemental light energy value

\section{1.はじめに}

イチジク果実は，小アジア地域を原産地とする亜熱带性植物1) であり，露地での栽培が主流である。わが国では，その収穫時期 は 8 月下旬から 9 月上旬に限られている。この季節の制約を排除 し収穫時期の多様化を図ることが, 商品としての付加価值を高め ることにつながると考えて, 温室内での栽培を試みることにした.

この試みの成否は, 温室内の環境をイチジク果実の成長に適し たものとすることにかかっており, 通常の露地栽培期に冬期を模 擬した環境を温室内に実現し，その中で人工的に制御すべき諸要 件の検討を試みる実験を行うことにした，本論文は，温室内に実 現すべき模擬環境の主要設定要因と考之られる，日射量の数值指 標の設定及び解明に至る諸検討の内容を述へ，その設定した指標 の実現手段についても言及している.

まず，温室内の模擬環境の設定要因を抽出するため，イチジク 果実の成長とそれに影響を与えると考之られる事項を調査し, 気 候要素としては気温と日照時間 (日射量) が重要であると判断し た．気温の調節は比較的容易であるので，以後の検討は日射量に 着目して進めることにした。次に，この実験を名古屋で実施する ことを踏まえて，世界におけるイチジクの主要産地と名古屋の気
候要素, 特に気温と日射量を比較・検討した。気温については気 象資料が得られ，イチジクの成長期（6月～9月）における主要 産地では, いずれも平均 $20^{\circ} \mathrm{C}$ 以上であることが判明し，これを温 度の成長要件とすればよいと判断した。しかし, 日射量について は, 資料が得られなかったので, 快晴時の直達日射量と日照時間 から各産地の気象に応じた直達日射量を計算し, 比較をした。

その結果一日の積算日射量の成長期4ケ月間にわたる平均值が, アテネで17.5MJ $\cdot \mathrm{m}^{-2} \cdot \mathrm{day}^{-1}$, サンディエゴで15.3MJ $\cdot \mathrm{m}^{-2}$ ・ $\mathrm{day}^{-1}$, 名古屋で $8.8 \mathrm{MJ} \cdot \mathrm{m}^{-2} \cdot \mathrm{day}^{-1}$ であり, 名古屋の日射量が他 の産地に比べて非常に少ないことが判明した。しかし, 名古屋が 露地栽培におけるわが国での主産地であることを考慮して, この 日射量を成長要件とすることが妥当であると考えた。上記の検討 結果に基づき，1月〜 3 月の期間に名古屋で温室栽培を行うこと を前提として，この期間について推定した野外の日積算日射量の 平均值 $6.1 \mathrm{MJ} \cdot \mathrm{m}^{-2} \cdot \mathrm{day}^{-1}$ からビニール被覆の透過効果を考虑し て温室内への入射量を求好る $3.7 \mathrm{MJ} \cdot \mathrm{m}^{-2} \cdot \mathrm{day}^{-1}$ が得られた.

従って, 果春が成熟し着色するためには, 成長期の日射量 8.8 か ら温公内の入射量 $3.7 の$ 差5.1が不足する日射量となる。この結果 より日射量の単位を除いた数值を人工光で補うための指標 5.1 と する。 


\section{2. 果実の産地}

\section{1 生産地}

イチジクの原産地の小アジアは, 地中海と黑海とに挟まれた西 アジアの半島地域, 面積は50万平方 $\mathrm{km}^{1}$ ほぼ゙であり, トルコが大部 分を占める。トルコ (イズミール), 地中海沿岸のギリシヤ(アテ ネ)，イタリア，ポルトガルなどの主生産地では年間約 60 万トン， わが国は愛知，福岡，広島などで約1.3万トン ${ }^{21}$ ，その内約 $24 \%$ が 愛知産で占められている。 その他では, 米国のカリフォルニア州 (サンディエゴ) なども産地である。先の地中海沿岸の地域は, 緯度が $38^{\circ} \mathrm{N} \sim 32^{\circ} \mathrm{N}$ に位㯰し，温带(緯度 $23.5^{\circ} \mathrm{N} \sim 66.5^{\circ} \mathrm{N}$ )の中で は熱帯に接近した地帯で要熱帯気候である。一年の中で平均気温 が $20^{\circ} \mathrm{C}$ 以上の月が $4 \sim 11$ 力あり, そのほかの $8 \sim 1$ ケ月は $20^{\circ} \mathrm{C}$ 以下の温暖な気候である。夏は, 降水量が少なく, 日照時間が長 いので，果実の栽培に適している。アテネにおける果実の栽培は, 5000年以前の頃からであり, 旧約聖書の創世記にも記されている. この地域には野生種のカプリ種が自生しているが, 栽培品種はス ミル十種である。さらに，サンディエゴには1759年にスペインの 宣教師によってスミルナ種がもたらされた。国内では，1909年(明 治42年)に栘井光次郎 (広島県出身)が, サンディエゴより現在の 主流の桝井ドーフィン種を輸入した。その外に，1624～1643年に 長崎に渡来した蓬萊柿などがある。

\section{2 果実の分類}

イチジクは曲熱帯性の果樹で, クワ科イチジク属の落葉小喬木 の植物である。果実は, 植物学的には偽果の一種でイヌビワの類 に見られる. 花の種類, 受粉の必要の有無により, 表 1 のよう カプリ種, スミル十種, サンペドロ種, 普通種の 4 品類に分類さ れる. 図 1 は果実の断面模式困であるが, 外側の花たくの部分と その内側にある小花で構成されている。眓は，桝井ドーフィン種 のものを示し小花数は2,000 2,800個ほどである.

\section{3 果実の成熟}

果実の成熟は，表 2 に示すように収穫前における果実の変化を 成熟期，収穫後の変化を後熟期という。種類により成熟期の間に 完熟するものと収穫後に追熟させて完熟にいたるものとがある. イチジクは前者であり，リンゴ，バナ十などは後者である。一般 に樹上で完熟する果実は完熟期に収穕したものが最も品質がよい

表 1 イチジク果実の品種と特徵 (長縄, 1987) ${ }^{2)}$

Table 1 The fig varieties and characteristics ${ }^{2)}$.

\begin{tabular}{|c|c|}
\hline 類 & 特 \\
\hline カプリ系 & $\begin{array}{l}\text { 南西アジアの野生種で, 花たく内に雄花と雌花が有る．栽塔 } \\
\text { 品種の祖先と見なされている．果実はブラストファーガの蜂 } \\
\text { の幼虫がおり，雄花が多いため食用にはできない. }\end{array}$ \\
\hline スミルナ系 & $\begin{array}{l}\text { 小アジアのスミル十地方で古くから栽培されている，花たく } \\
\text { には䧳花しかなく，カプリ種の受粉により結奏する，蜂の成 } \\
\text { 虫が花粉を運ぶ，食用は乾果であり，国内では栽培していな } \\
\text { い. }\end{array}$ \\
\hline $\begin{array}{l}\text { サンペドロ } \\
\text { 系 }\end{array}$ & $\begin{array}{l}\text { 結実の䏨性はスミル十種と普通種の中間にあたる。夏果は単 } \\
\text { 為結実する，秋果は受粉が必要。国内にはビオレードーフィ } \\
\text { ンやサンペドロホワイトなどの夏果専用種がある. }\end{array}$ \\
\hline 普 通 系 & $\begin{array}{l}\text { ・桝井ドーフィン：国内の栽培品種の殆どを占めている. 夏 } \\
\text { 秋果兼用種で, 受粉せずに, 単為結実する. 食用の果肉は花 } \\
\text { たく, 小花 (雌花) 部分である. }-6{ }^{\circ} \mathrm{C} \text { 以下の低温で涷害を受 } \\
\text { ける } \\
\text { ・莑莱柿；国内, 最古の品種で耐寒性がある. }\end{array}$ \\
\hline
\end{tabular}

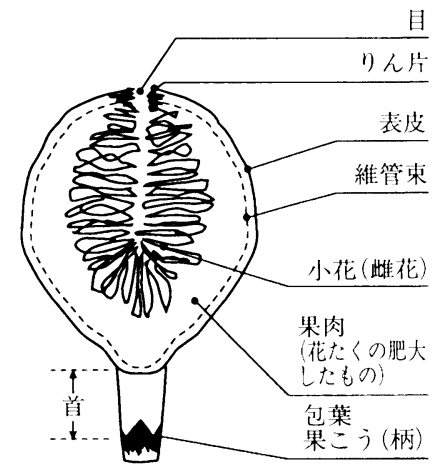

図 1 イチジク果実の断面模式図 (長縄, 1987) ${ }^{2)}$

Fig. 1 The internal view of a ripe $\mathrm{fig}^{2)}$.

表 2 果実の成熟期と後熟期の区分（伊庭ら, 1985 $)^{31}$ Table 2 Features of the fig growth period ${ }^{31}$.

\begin{tabular}{|c|c|c|}
\hline \multicolumn{2}{|r|}{ 熟＼cjkstart期 } & 段階的区分 \\
\hline \multirow{4}{*}{$\begin{array}{l}\text { (A) } \\
\text { 成 } \\
\text { 熟 } \\
\text { 期 }\end{array}$} & $\begin{array}{c}\text { 未熟期 } \\
\text { (immature) }\end{array}$ & $\begin{array}{l}\text { 樹上において食味がまだ充分でない段階, 又は収穫後 } \\
\text { に完熟する種類では追熟処理によっても食味が无分に } \\
\text { 発達しない段階. }\end{array}$ \\
\hline & $\begin{array}{l}\text { 適熟期 } \\
\text { (mature) }\end{array}$ & $\begin{array}{l}\text { 樹上において叮食状態に達した段階，又は収穫後に穵 } \\
\text { 熟する種類では追熟処理で水準以上の食味吅上が期待 } \\
\text { できる成熟の段階. }\end{array}$ \\
\hline & $\begin{array}{l}\text { 完熟期 } \\
\text { (ripe) }\end{array}$ & 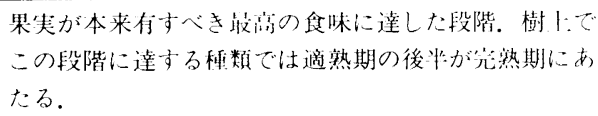 \\
\hline & $\begin{array}{l}\text { 過熟期 } \\
\text { (over-mature) } \\
\text { (over-ripe) }\end{array}$ & $\begin{array}{l}\text { 樹上で食味の低トが顕著になった段階，又は収穕後の } \\
\text { 追熟処理により正常に完熟できない成熟の段階. }\end{array}$ \\
\hline & (B) 後熟期 & $\begin{array}{l}\text { 収穫淔後から果実の食味が低下して嗜好性が失われる } \\
\text { までの期間をいう。 この期間中・食味が低下゙すだけ } \\
\text { のもの・追熟が必要なもの，に分けられる。 }\end{array}$ \\
\hline
\end{tabular}

が，日持ちが低下することが多い。しかし，イチジクを完熟前に 収穕すると硬度は漸次減少するものの着色の進行及び糖含量の増 加は全く期待できず食味が充分でないまま劣化するので, 適熟期 まで樹上に置かれる. なお, 後熟期とは, 収穫直後から果実の食 味が低下して嗜好性が失われるまでの期間である.

\section{4 果実の成熟プロセス \\ 2.4 .1 着果の習性}

国内で栽培されている品種の大部分は果実の重量が大きく，収 穫量の多い栘井ドーフィン種である。この種は夏秋兼用種である。 夏果は 前年生枝を切り返しせずに放任すると，越冬果がそのま ま肥大成長し， 6 月頃に成熟する。収穫果数, 収量とも少ない. そのう之秋果の収量が極めて減少する。この方法は現在殆ど利用 されていない，秋果は前年生枝の切り返し剪定を行い，基部の芽 を萌芽させ新梢をつくる．果実の花芽は新梢の之き芽である。こ の方法が広く普及している。新梢の伸長は 4 月下旬頃始まり，8 月中旬まで続く。花芽分化果は新梢の基部 $2 \sim 3$ 節を除いて，上 部の葉之きに順次果実が着き，下方の果実より順番に成熟する.

\section{4 .2 果実の成長曲線}

イチジク果実は樹上で成熟の過程を経て，完熟に達するが，そ の成長度は, 図 2 に示すような二重 S 字型曲線となる。果実は 6 月中旬 7 月上旬と成熟直前の 8 月中旬に急激に成長する。 7 月 中旬から成熟期までは緩やかな成長をする。 


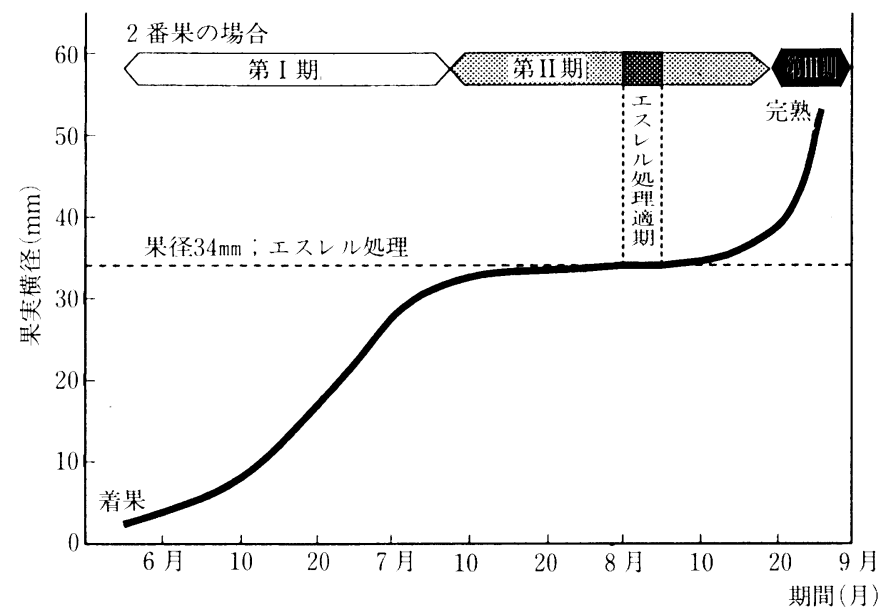

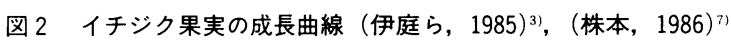
Fig. 2 The fig growth curve ${ }^{377}$.

表 3 イチジク果実の成長の 3 時期 (伊庭ら, 1985) ${ }^{31}$ Table 3 The 3 stages of fig growth ${ }^{3)}$.

\begin{tabular}{|c|c|c|c|c|}
\hline 時 期 & 区 分 & 期 間 & 日数 & 細胞組織 \\
\hline 第 I 期 & $\begin{array}{l}\text { 第 } 1 \text { 急速 } \\
\text { 成交期 }\end{array}$ & $\begin{array}{c}6 \text { 月上的 } \\
\sim 7 \text { 月上的 }\end{array}$ & 40 & $\begin{array}{l}\text { 分裂と增殖 } \\
\text { 重螷20日程度 }\end{array}$ \\
\hline 第 II 期 & $\begin{array}{c}\text { 成良 } \\
\text {-一時停水期 }\end{array}$ & $\begin{array}{l}7 \text { 月1:旬 } \\
-8 \text { 月中约 }\end{array}$ & 35 & 重量は殆ど增㞦しな \\
\hline 第III期 & $\begin{array}{l}\text { 第 } 2 \text { 急速 } \\
\text { 成攴期 }\end{array}$ & $\begin{array}{c}\text { 8月下的 } \\
\text { (戊熟南前) }\end{array}$ & 10 & $\begin{array}{l}\text { 容稹の增大 } \\
\text { 重量 } 100 \mathrm{~g} \text { 以上: }\end{array}$ \\
\hline
\end{tabular}

この成長速度の違いから，表３のように区分されている．各組 織の細胞分裂の停止は皮層内部で早く，表皮で遅いが，第 I 期の 末には終了する。

\section{4 .3 果実の重量と糖度}

果実の重量は第 $\mathrm{I}$ 期の終り頃 $20 \mathrm{~g}$ 程度となり，その後殆ど増加 しない. 第III期に入ると急增して $100 \mathrm{~g}$ 以上に肥大する. 表皮は赤 茶色となり，柔らかくなる，食味としての糖含量については糖の 大部分が還元糖である。糖度は，図 3 のように第 I 期〜第 II 期の 終りまでは $2.0 \%$ から $6.7 \%$ へと漸増するが，第III期に入ると急增 し，成熟期には $11.5 \%$ に達する。非還元糖は成長初期には殆どみ られず第III期中期に僅かに増加し $1.0 \%$ 程度となる.その後ふたた び減少して成熟果には殆どみられない.澱粉含量は初期には $0.3 \%$ 程度と少ないが，その後直線的に増加して第II期中期には $3.8 \%$ と 最高となり，その後減少し成熟期にはさらに減少する。点線で表 わした遊㒕酸はリンゴ酸として換算したものである。

\section{4 .4 果実の形質変化}

果実成長が第III期に入ると成熟促進のためのホルモン剤の添加 (エスレル処理という) を目の部分に行う。処理後に収穕適期に なった時の果実形質（色調，果実重量，糖含量，果肉硬度）は, その収穫時期により図 4 のように変化する傾向を示す。表 4 はこ の四より果実の生育に関わる気温の影響をまとめたものである. 特に，9月中旬〜 10 月上旬の降雨による日照不足の影響は果実品 質を悪化させる。それは，着色の進行が著しく抑制され，糖含量 の増加が抑制される。10月上旬の降雨は，果実腐敗を増大する。

\subsection{5. 果実の熟度と品質}

イチジク果実は, 樹上で完熟したものを収穫し, 熟度の判定が 表 5 のように未熟, やや未熟, 適熟, 完熟の 4 段階あって, 各段

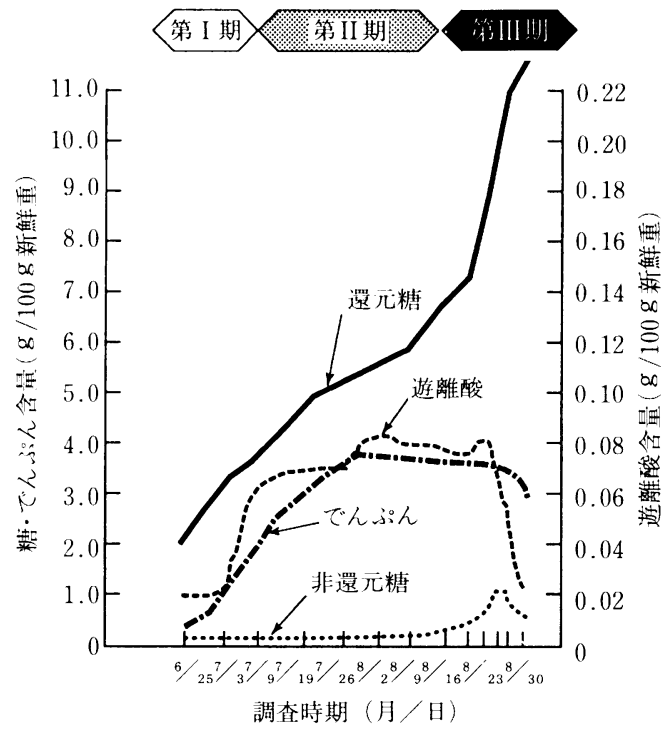

図3イチジク果実の成長期の喏度等成分の消長 (伊庭ら, 1985) ${ }^{3)}$ Fig. 3 The sugar content of fig during growing period ${ }^{3)}$.
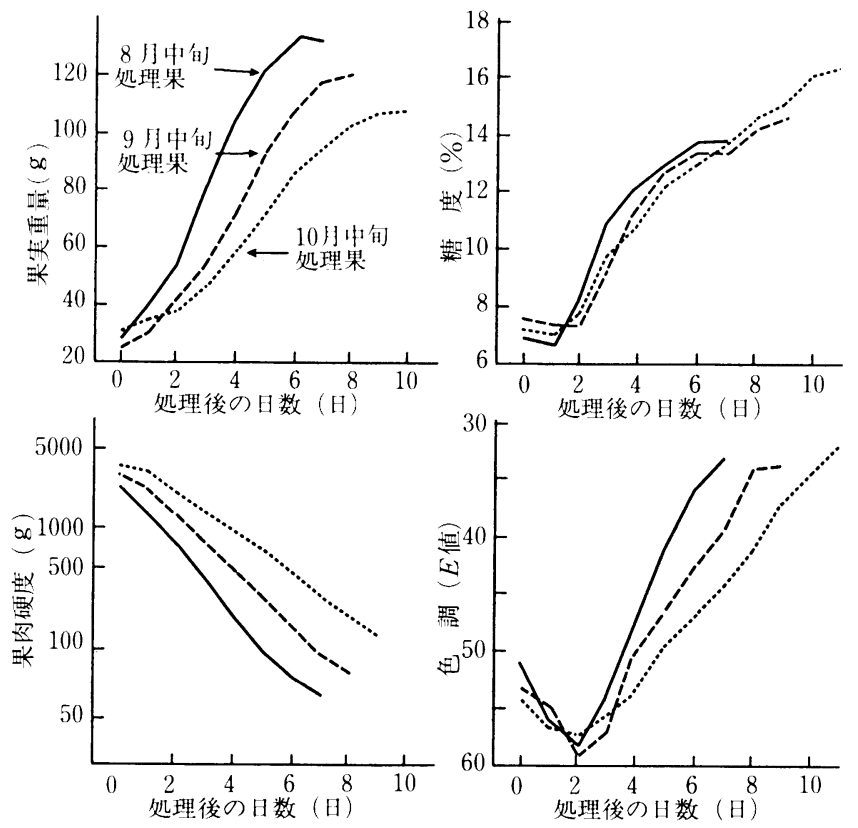

図 4 エスレル処理後の果実の形質变化（伊庭ら, 1985 $)^{3}$

Fig. 4 The impact of fig after maturation actuator treatment ${ }^{3)}$.

表 4 果実のエスレル(成熟促進剤)処理時期と気温の関係(伊庭ら, 1985) ${ }^{3 !}$ Table 4 The relation between temperature and actuator treatment ${ }^{3)}$.

\begin{tabular}{|c|c||c|c|c|c|}
\hline $\begin{array}{c}\text { エスレス } \\
\text { 処理時期 }\end{array}$ & 父温 & $\begin{array}{c}\text { 着色度 } \\
(7 \sim 8 \text { 分 })\end{array}$ & $\begin{array}{c}\text { 重星 } \\
(\mathrm{g})\end{array}$ & $\begin{array}{c}\text { 糖旨 } \\
(\%)\end{array}$ & $\begin{array}{c}\text { 㹬度 } \\
(\mathrm{g})\end{array}$ \\
\hline 8 月中旬 & $\begin{array}{c}21^{\circ} \mathrm{C} \\
\text { 以上 }\end{array}$ & $\begin{array}{c}\text { 処理後, } \\
5 \sim 6 \text { 日経過 }\end{array}$ & 130 & 13.0 & 80 \\
\hline 9 月中旬 & $\begin{array}{c}20^{\circ} \mathrm{C} \\
\text { 前後 }\end{array}$ & $\begin{array}{c}\text { 処理後, } \\
6 \sim 7 \text { 日経過 }\end{array}$ & 115 & 13.5 & 110 \\
\hline 10 月上旬 & $\begin{array}{c}19^{\circ} \mathrm{C} \\
\text { 以下 }\end{array}$ & $\begin{array}{c}\text { 処理後, } \\
9 \sim 10 \text { 日経過 }\end{array}$ & 100 & 15.0 & 135 \\
\hline
\end{tabular}

注） *1.表皮の着色は，農水省果樹試製イチジク用カラーチャートによる *2. 果肉硬度は, $\phi 3 \mathrm{~mm}$ の円柱針で突き刺した時の最大応力 
表 5 イチジク果実の熟度と果実品質(伊庭ら, 1985) $)^{3)}$

Table 5 The fig maturation and quality levels ${ }^{3}$.

\begin{tabular}{|c|c|c|c|c|c:c|}
\hline $\begin{array}{c}\text { 果実 } \\
\text { 熟度 }\end{array}$ & $\begin{array}{c}\text { 着色度 } \\
(\text { 分 })\end{array}$ & $\begin{array}{c}\text { 色調 } \\
(E \text { 値 })\end{array}$ & $\begin{array}{c}\text { 重量 } \\
(\mathrm{g})\end{array}$ & $\begin{array}{c}\text { 硬度 } \\
(\mathrm{g})\end{array}$ & $\begin{array}{c}\text { 糖 度 } \\
(\%)\end{array}$ & $\begin{array}{c}\text { 還元糖 } \\
(\%)\end{array}$ \\
\hline 未熟 & $2 \sim 3$ & 49.2 & 91 & 268 & 11.7 & 10.5 \\
\hline やや未熟 & $4 \sim 5$ & 44.7 & 110 & 155 & 12.8 & 11.9 \\
\hline 適熟 & $7 \sim 8$ & 38.7 & 128 & 114 & 13.5 & 12.6 \\
\hline 完熟 & 9 以上 & 36.0 & 136 & 61 & 14.2 & 13.1 \\
\hline
\end{tabular}

注）1. 色調: $E=\sqrt{L^{2}+a^{2}+b^{2}}$

2 . 硬度： $\phi 3 \mathrm{~mm}$ の円柱針で突き刺した時の最大応力

階の概数值（表皮の着色度，重量，硬度，糖度）がある，例之ば 完熟果の場合，着色度は 9 以上，色調の $E$ 值は（CIE1976の $L^{*} a^{*} b^{*}$ 表色系) で 36 , 重量 $136 \mathrm{~g}$ ，果肉硬度 $61 \mathrm{~g}$, 糖度 $14.2 \%$ とな っている.

\section{3. 生産地の気候要素}

\section{1 生産地の調査}

果実の産地として地中海沿岸の諸国，アメリカ，日本の調査対 象地14を挙げ，整理した。次に，気象庁統計室及び理科年表（東 京天文台編）により気象資料を調査した。その内，果実の成長に 影響がある気候要素は(1)気温(2)相対湿度(3)日照時間(4)降水量の 4 項目とし, 表 6 に地域別の果実生産地区分と気候要素の有無を示

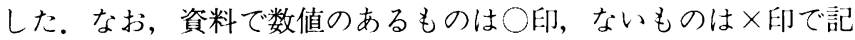
入した。これより要素(1)〜(4)の全て揃っている 5 地域は, スペイ ン，イタリア，ギリシア，アメリカ，日本であった。ポルトガル とトルコ・キプロスは湿度または日照時間が欠落しているが，そ の他の資料はグループの補完用として残した。

\section{2 主要産地の気候要素の対比}

アテネ，イズミール，サンディエゴ，名古屋の一年間の気温， 湿度，日照時間，降水量の值が変化する状態を図 5 で表した。

表 7 は，果実の露地栽培時期が 6 月〜 9 月なので，この 4 ケ月 間の気候要素 4 項目をアテネ基準として対比したものである。気 温は，最高気温が $24 \sim 26^{\circ} \mathrm{C}$ の範囲で，ほぼ同程度であるが，いず れの産地も共通して，この 4 ケ月間は $20^{\circ} \mathrm{C}$ 以上となっている．湿

表 6 果実の生産地区分と気候要素の有無 $\left(\right.$ 気象庁, 1996) ${ }^{41}$

(東京天文台, 1994) (1) $^{5}$

Table 6 The climate data of major fig producing areas ${ }^{455}$.

\begin{tabular}{|c|c|c|c|c|c|c|}
\hline 国名 & 観測地名 & $\begin{array}{c}\text { 緯度 } \\
\mathrm{N}\end{array}$ & $\begin{array}{l}\text { 気 } \\
\text { 温 }\end{array}$ & $\begin{array}{l}\text { 湿 } \\
\text { 度 }\end{array}$ & $\begin{array}{l}\text { 日 } \\
\text { 照 }\end{array}$ & $\begin{array}{l}\text { 降 } \\
\text { 水 }\end{array}$ \\
\hline ポルトガル & $\begin{array}{c}\text { *リスボン } \\
\text { ファロ }\end{array}$ & $\begin{array}{l}38.78^{\circ} \\
37.02\end{array}$ & $\begin{array}{l}0 \\
0\end{array}$ & $\begin{array}{l}0 \\
\times\end{array}$ & $\begin{array}{l}\times \\
0\end{array}$ & $\begin{array}{l}0 \\
0\end{array}$ \\
\hline スペイン & マラガ & 36.87 & 0 & 0 & 0 & 0 \\
\hline イタリア & *ナポリ & 40.85 & 0 & 0 & 0 & 0 \\
\hline ギリシャ & *アテネ & 37.97 & 0 & 0 & 0 & O \\
\hline $\begin{array}{l}\text { トルコ } \\
\text { キプロス }\end{array}$ & $\begin{array}{c}* \text { イズミール } \\
\text { カルナカ }\end{array}$ & $\begin{array}{l}38.43 \\
34.88\end{array}$ & $\begin{array}{l}0 \\
0\end{array}$ & $\begin{array}{l}0 \\
\times\end{array}$ & $\begin{array}{l}\times \\
0\end{array}$ & O \\
\hline アメリカ & *サンディエゴ & 32.73 & 0 & O & 0 & 0 \\
\hline 日本 & * 名古屋 & 35.17 & 0 & 0 & 0 & 0 \\
\hline
\end{tabular}

注）気候要素資料の出典

1。*印は，理科年表：東京天文台編1994（丸善） その他は気象庁統計資料：1996.1 12のデー夕

3 、気候要素欄：デー夕有○，無し×の記号で示寸.
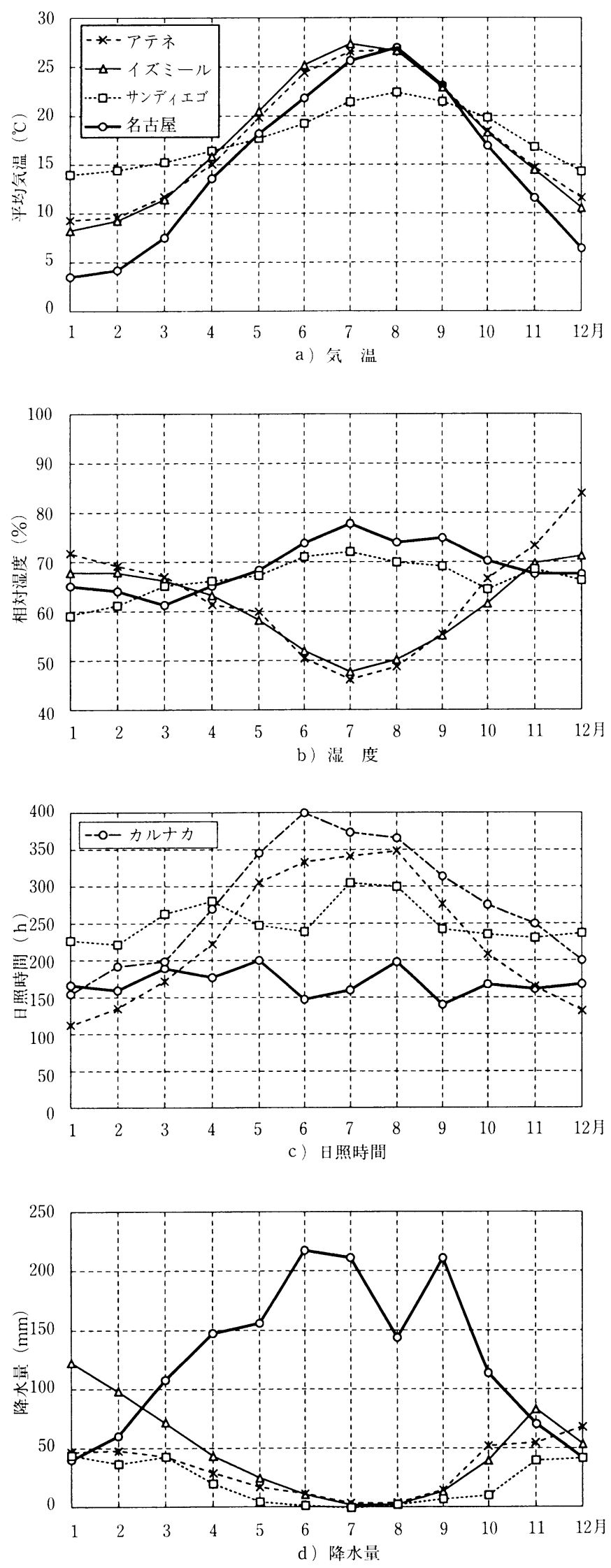

図 5 主生産地の一年間の気候要素の変化

Fig. 5 The annual climate data of major fig producing areas. 
表 7 気候要素の対比（アテネ基準）

Table 7 The climate data of Athens, San Diego and Nagoya.

\begin{tabular}{|c|c|c|c|c|}
\hline (a) 気温 $\left({ }^{\circ} \mathrm{C}\right)$ & $\begin{array}{c}4 \text { ケ月平均值 } \\
(6-9 \text { 月 })\end{array}$ & 差 & 年平均 & 差 \\
\hline $\begin{array}{l}\text { アテネ(ギリシア }) \\
\text { イ゙ミール(トルコ }\end{array}$ & $\begin{array}{l}25.4 \\
25.8\end{array}$ & $\begin{array}{l}\text { 基準 } \\
0\end{array}$ & $\begin{array}{l}17.7 \\
17.7\end{array}$ & $\begin{array}{c}\text { 基潐 } \\
0\end{array}$ \\
\hline サンディエゴ & 21.3 & +0.1 & 17.8 & +0.1 \\
\hline 名战屋 & 24.5 & -2.7 & 15.0 & -2.7 \\
\hline (b) 淇显度 $(\%)$ & $\begin{array}{c}4 \text { 个月平均值 } \\
(6-9 \text { 月 })\end{array}$ & 差 & 年平均 & 差 \\
\hline $\begin{array}{l}\text { アテネ(ギリシア } \\
\text { イズミール(トルコ) }\end{array}$ & $\begin{array}{l}49.3 \\
50.3\end{array}$ & $\begin{array}{l}\text { 基準 } \\
+2.0\end{array}$ & $\begin{array}{l}62.4 \\
60.4\end{array}$ & $\begin{array}{l}\text { 基準 } \\
-2.0\end{array}$ \\
\hline サンディエゴ & 70.5 & +21.2 & 66.5 & +4.1 \\
\hline 名古屋 & 75.3 & +26.0 & 69.1 & +6.7 \\
\hline (c) H照時間 (h) & $\begin{array}{c}4 \text { ケ月平均值 } \\
(6-9 \text { 月 }\end{array}$ & 比率 & 年平均值 & 比率 \\
\hline $\begin{array}{c}\text { アテネ(ギリシア) } \\
\text { カルナカ(キプロス) }\end{array}$ & $\begin{array}{l}327 \\
363\end{array}$ & $\begin{array}{l}\text { 基準 } \\
111.0\end{array}$ & $\begin{array}{l}230 \\
278\end{array}$ & $\begin{array}{l}\text { 基準 } \\
120.9\end{array}$ \\
\hline サンディエゴ & 270 & 82.6 & 252 & 109.6 \\
\hline 名古屋 & 160 & 48.9 & 168 & 73.0 \\
\hline (d) 降水量 $(\mathrm{mm})$ & $\begin{array}{c}4 \text { 个月评均値 } \\
(6-9 \text { 月 })\end{array}$ & 比率 & 年平均値 & 比率 \\
\hline $\begin{array}{l}\text { アテネ(ギリシア) } \\
\text { イスミール(トルコ) }\end{array}$ & $\begin{array}{l}8 \\
6\end{array}$ & $\begin{array}{l}\text { 基集 } \\
0.75\end{array}$ & $\begin{array}{l}33 \\
47\end{array}$ & $\begin{array}{l}\text { 基潐 } \\
1.4\end{array}$ \\
\hline サンディエゴ & 3 & 0.38 & 21 & 0.6 \\
\hline 名古屋 & 197 & 24.6 & 128 & 3.9 \\
\hline
\end{tabular}

度は， 7 月にアテネが乾期で最低值の $49 \%$ ，名古屋が梅雨期のた め最大值の75\%であり，この時期の降水量はアテネの約 $2500 \%$ と なる。目照時間は，アテネの半分以下と短く成熟期における表皮 の着色促進に不利となっている。

\section{4. 日射量の算定}

\section{1 直達日射量の計算}

前項では，資料収集が可能であった気候要素即ち，気温，降水 量や日照時間などについて，世界の主要産地の比較を試みたが, これら以外にイチジク果実の成熟に影響を与える気候要素とし て，各産地の日射量が考えられる。そこで，産地の緯度が既知で あれば，昼間の時間数（昼間時数）が，さらに年間を通して快晴 であると仮定すると直達日射量が計算により求められること，お よび産地の日照時間が資料として得られていることに着目して, 各月の平均の日積算日射量を推定して，それの産地間の比較対照 を試みた。即ち，1997年の各日の太陽赤緯 $\delta$ を参照して，各産地 の緯度 $\phi$ に応じて, 日出 (日没) 時の時角 $t$ 在次式9)で算出した。

$t= \pm \cos ^{-1}(-\tan \phi \tan \delta)$

これを次式で時間数に変換して各日の昼間時数 $T_{\mathrm{d}}$ を求めた。

$T_{\mathrm{d}}=2 t / 15$

この各山の昼間時数を各月にわたって集計した月間の昼間時数 $T_{\mathrm{m}}$ に対寸る资料として得られた日照時間 $\mathrm{T} の$ 比が，各月の日照 率 $R$ の推定值となる.一方, 緯度 $\phi$ と太陽赤緯 $\delta$ と時角 $t$ が既知 であれば，その時の太陽高度 $h$ は次式で与えられる。

$\sin h=\sin \phi \sin \delta+\cos \phi \cos \delta \cos t$

その時の快晴時の水平面での值達日射量 $J_{\mathrm{H}}$ は, ブーゲの式6)と

して次式で得られる。

$J_{\mathrm{H}}=J_{0} \cdot P^{\operatorname{cosec} h} \cdot \sin h$
ここに， $J_{0}:$ 太陽定数 $\left(1360 \mathrm{~W} \cdot \mathrm{m}^{-2}\right.$ とした $)$

$$
P: \text { 大気透過率 }(0.7 \text { とした })
$$

この日射照度を一日にわたって積算した日積算日射量の各月の 平均值を求めると, 常時快晴であるとした場合の日積算日射量の 月平均值が推定できる。このよjにして得たのが表 8 である.

表中は，(a)アテネ，サンディエゴの 4 月〜10月，(b)名古屋の一 年間における日積算日射量の月平均值の推定過程と結果を示した ものである。これらの推定結果に基づいて地域別の日射量を比較 検討したものが表 9 である。これより，4 ケ月間の日積算值の合

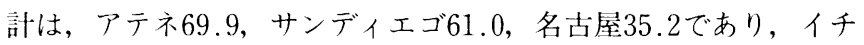
ジクの成長期に拐ける名古屋の日射量が, アテネとサンディエゴ に比べて著しく少ないことがわかる．アテネと名古屋を比較する と, 成長期の第 I 期の 6 月， 7 月における日射量の差異は非常に 大きく，名古屋ではアテネの半分以下の值となっており，第II期 の 8 月, 第III期の 9 月においては50\%を超えるものの, 60\%以下 である。ここでは，薷天時にも存在する全天日射量を無視した推 定を行ったが，それを加味したとしても名古屋の日射量は，アテ ネやサンディエゴに比べて非常に少ないことがわかった。

\section{表 8 地域別の日積算日射量（值達）の月平均値（推定値）}

Table 8 A comparison of direct solar radiation energy of Athenes, San Diego, and Nagoya.

(a) アテネ (上段)・サンディエゴ (下段)

日射量〔单位： $\mathrm{MJ} \cdot \mathrm{m}^{-2} \cdot \mathrm{day}^{-1}$ 〕

\begin{tabular}{|c|c|c|c|c|c|}
\hline \multirow{2}{*}{$\begin{array}{l}\text { 期間 } \\
(\text { 月) }\end{array}$} & \multirow{2}{*}{$\begin{array}{c}\text { 昼間時数 } \\
T_{\mathrm{m}} \\
(\mathrm{h})\end{array}$} & \multirow{2}{*}{$\begin{array}{c}\text { 日照時間 } \\
T \\
(\mathrm{~h})\end{array}$} & \multirow{2}{*}{$\begin{array}{c}\text { 日照摔 } \\
R= \\
T^{R} / T_{\mathrm{m}}\end{array}$} & \multicolumn{2}{|c|}{ 日積算日射星の月平均值 } \\
\hline & & & & $\begin{array}{c}\text { 常時快晴 } \\
\Sigma J\end{array}$ & $\begin{array}{c}\text { 旦照率考虐 } \\
\Sigma J^{\prime}=R \cdot \Sigma J\end{array}$ \\
\hline \multirow[t]{2}{*}{4} & 391 & 223 & 0.57 & 20.2 & 11.5 \\
\hline & 386 & 282 & 0.73 & 21.4 & 15.6 \\
\hline \multirow[t]{2}{*}{5} & 436 & 307 & 0.70 & 23.9 & 16.7 \\
\hline & 425 & 246 & 0.58 & 24.4 & 14.2 \\
\hline \multirow[t]{2}{*}{6} & 438 & 334 & 0.76 & 25.5 & 19.4 \\
\hline & 424 & 240 & 0.57 & 25.6 & 14.6 \\
\hline \multirow[t]{2}{*}{7} & 459 & 343 & 0.75 & 25.6 & 19.2 \\
\hline & 446 & 305 & 0.69 & 25.8 & 17.8 \\
\hline \multirow[t]{2}{*}{8} & 417 & 351 & 0.84 & 21.8 & 18.3 \\
\hline & 409 & 297 & 0.73 & 22.6 & 16.5 \\
\hline \multirow[t]{2}{*}{9} & 368 & 280 & 0.76 & 17.1 & 13.0 \\
\hline & 367 & 239 & 0.65 & 18.6 & 12.1 \\
\hline \multirow[t]{2}{*}{10} & 343 & 207 & 0.60 & 11.8 & 7.1 \\
\hline & 348 & 233 & 0.67 & 13.8 & 9.3 \\
\hline
\end{tabular}

(b) 名古屋

$\mathrm{H}$ 射娄 (単位: $\mathrm{MJ} \cdot \mathrm{m}^{-2} \cdot \mathrm{day}^{-1}$ )

\begin{tabular}{|c|c|c|c|c|c|}
\hline \multirow{2}{*}{$\begin{array}{l}\text { 期間 } \\
\text { (月) }\end{array}$} & \multirow{2}{*}{$\begin{array}{c}\text { 昼間時数 } \\
T_{\mathrm{m}} \\
(\mathrm{h})\end{array}$} & \multirow{2}{*}{$\begin{array}{c}\text { 日照時間 } \\
T \\
(\mathrm{~h})\end{array}$} & \multirow{2}{*}{$\begin{array}{c}\mathrm{H} \text { 照保 } \\
R= \\
T / T_{\mathrm{m}}\end{array}$} & \multicolumn{2}{|c|}{$\mathrm{H}$ 稓算日射量の月平均值 } \\
\hline & & & & $\begin{array}{c}\text { 常時快晴 } \\
\sum J\end{array}$ & $\begin{array}{l}\text { 日照摔考慮 } \\
\Sigma J^{\prime}=R \cdot \Sigma J\end{array}$ \\
\hline 1 & 308 & 167 & 0.54 & 7.6 & 4.1 \\
\hline 2 & 302 & 159 & 0.53 & 11.1 & 5.9 \\
\hline 3 & 367 & 190 & 0.52 & 16.1 & 8.4 \\
\hline 4 & 388 & 177 & 0.46 & 20.9 & 9.6 \\
\hline 5 & 430 & 202 & 0.47 & 24.2 & 11.4 \\
\hline 6 & 430 & 146 & 0.34 & 25.5 & 8.7 \\
\hline 7 & 452 & 157 & 0.35 & 25.7 & 9.0 \\
\hline 8 & 412 & 196 & 0.48 & 22.3 & 10.7 \\
\hline 9 & 368 & 139 & 0.38 & 17.9 & 6.8 \\
\hline 10 & 346 & 163 & 0.47 & 12.8 & 6.0 \\
\hline 11 & 306 & 157 & 0.51 & 8.6 & 4.4 \\
\hline 12 & 300 & 162 & 0.54 & 6.6 & 3.2 \\
\hline
\end{tabular}


表 96 月〜 9 月直達日射量の計算値の対比

Table 9 A comparison of direct solar radiation energy from June to September.

\begin{tabular}{|c|c|c|c|c|c|}
\hline 期間（月） & (1)アテネ & (2)Hンディエゴ & (3)名㨁屋 & $\begin{array}{l}\text { 不足分 } \\
\text { (1)-(3) }\end{array}$ & (3) $/$ 比率 \\
\hline 6 & 19.4 & 14.6 & 8.7 & 10.7 & 0.45 \\
\hline 7 & 19.2 & 17.8 & 9.0 & 10.2 & 0.47 \\
\hline 8 & 18.3 & 16.5 & 10.7 & 7.6 & 0.58 \\
\hline 9 & 13.0 & 12.1 & 6.8 & 6.2 & 0.52 \\
\hline 合 計 & 69.9 & 61.0 & 35.2 & 34.7 & 0.50 \\
\hline 月平均 & 17.5 & 15.3 & 8.8 & 8.7 & 0.50 \\
\hline
\end{tabular}

\section{2 温室内の所要日射量の推定}

まず，野外の日射量の算定は，気候資料が得られなかったので， 快晴時の直達日射量と日照時間から各産地の気象に応じた直達日 射量を計算し，比較した。その結果，表 9 に示したように，イチ ジクの成長期（6月～9月）の一日の積算日射量の月平均值が, アテネで17.5MJ $\cdot \mathrm{m}^{-2} \cdot \mathrm{day}^{-1}$, 名古屋で $8.8 \mathrm{MJ} \cdot \mathrm{m}^{-2} \cdot \mathrm{day}^{-1} て ゙$ あり，名古屋の日射量は，アテネの約 $50 \%$ と非常に少ない。しか し，名古屋が露地栽培の主産地であることを考虑して，この日射 量を成長要件とすることが妥当であると考えた．上記の検討結果 に基づき，1月〜 3 月の期間に名古屋で温室栽培を行うことを前 提として, 表 8 (b)から, この期間の野外の日積算日射量の平均値

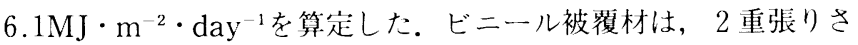
れており，透過率を日立製分光光度計 UV-3400により測定した資 料 ${ }^{8)}$ にると, 図 6 のように, 250〜 450nmの波長域で透過率が減 少することが示されている. 従ってこのビニール被覆材の透過率 を全波長域を通じて $60 \%$ と仮定して温室内の入射量を求めると $3.7 \mathrm{MJ} \cdot \mathrm{m}^{-2} \cdot \mathrm{day}^{-1}$ が得られた。これより果実が成熟し着色する ためには, 成長期の日射量 8.8 から温室内の入射量 $3.7 の$ 差 5.1 が不 足量であり，これを数值指標とすることにした。実験の実施時期 は，8月〜 月月であり，この期間の野外の日積算日射量の平均值 8.8 , 図 7 のようにビニール被覆（2 重）の透過率60\%で3.5, 遮光用の寒冷紗の透過率 $70 \%$ を張ると 1.6 が損失し, 箺験の設定値 3.7 得られる。この場合の総合透過率は $40 \%$ になる。言い換えれ ば不足日射量を人工的に補う数值指標 5.1 が果実の成熟には不可 欠であると考えられる。ささらに，ビニール被覆（2重）による波 長域の減少分が着色には大きく影響すると考えられるので, この

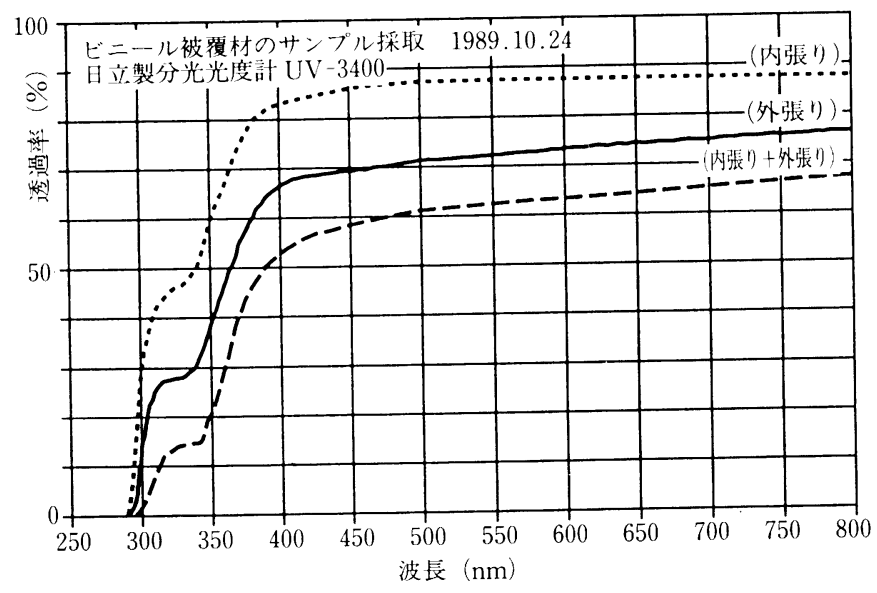

図 6 ビニール被覆材の分光透過率の測定值（柳原, 1990) $)^{8)}$ Fig. 6 The spectral transmittance of vinyl film ${ }^{8)}$.
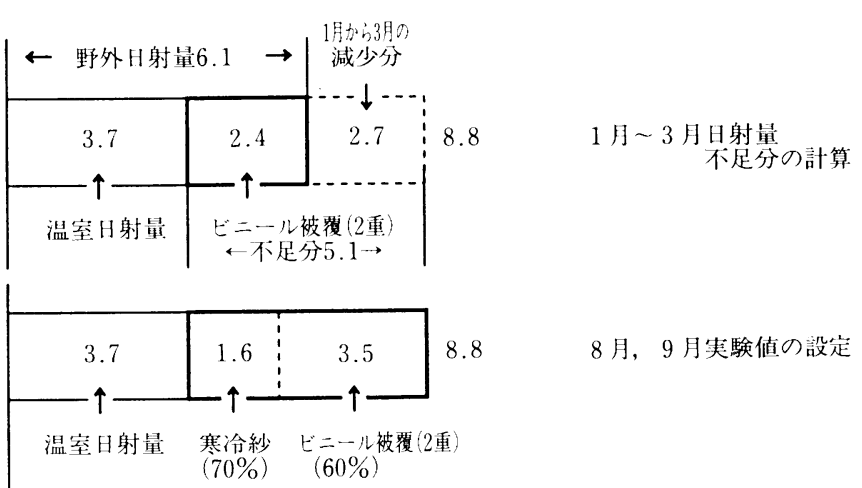

温室内の所要月平均日射量の設定

図 7 温室内の月平均日射量(不足分)の計算

Fig. 7 A supplemental light energy value estimated for direct solar radiation deficiency in a green house.

部分の補償も重要と考えられる。

\section{5. 結言}

イチジク果実は亜熱带性植物で偽果の一種であり，原産地の気 候に梁く関わりがある。とりわけ成熟期の日射量は果実の形質, 特に色素の生成に作用して，表皮の着色促進に影響していると推 定される，名古屋において，年間日射量が低くなる 1 月〜 3 月に ビニール被覆温室内で栽培が試みられた結果でも表皮の着色促進 が劣り，品質的な課題を生じていた。そのような理由から月平均 日射量を算定し，原産地のアテネと対比した結果，

(1)収穫期の 6 月〜 9 月の時期は, $8.8 \mathrm{MJ} \cdot \mathrm{m}^{-2} \cdot \mathrm{day}^{-1}$ で, 8.7 $\mathrm{MJ} \cdot \mathrm{m}^{-2} \cdot \mathrm{day}^{-1}$ も低い值となった。

(2) 1 月〜 3 月の野外の月平均日射量は $6.1 \mathrm{MJ} \cdot \mathrm{m}^{-2} \cdot \mathrm{day}^{-1}$ で, 6 月〜 9 月の時期よりも更に, $2.7 \mathrm{MJ} \cdot \mathrm{m}^{-2} \cdot \mathrm{day}^{-1}$ の光量が減少 している.

(3)ビニール被覆 2 重張り温室は, 光透過率 $60 \%$ なので, 減光量は $2.4 \mathrm{MJ} \cdot \mathrm{m}^{-2} \cdot \mathrm{day}^{-1}$ となり，投入日射量は， $3.7 \mathrm{MJ} \cdot \mathrm{m}^{-2} \cdot \mathrm{day}^{-1}$ と推定された。

(4) 8 月，9月を実験時期に設定したので，温室を 1 月〜 3 月の状 態にするため光透過率70\%の寒冷紗を張るとさらに 1.6 $\mathrm{MJ} \cdot \mathrm{m}^{-2} \cdot \mathrm{day}^{-1}$ の減光量となり, ビニール被覆 2 重張りの光 透過率 $60 \%$ の減光量 $3.5 \mathrm{MJ} \cdot \mathrm{m}^{-2} \cdot \mathrm{day}^{-1}$ 上り, 不足光量は 5.1 $\mathrm{MJ} \cdot \mathrm{m}^{-2} \cdot \mathrm{day}^{-1}$ となった。

(5)更に, ビニ一ル被覆張りのため, 290〜 470nm 波長域の透過率が 低くなった。この波長域が着色に影響を与えると考えられるの で，ここの波長域を人工照明で補強することが必要である．以 上のことより, 表皮の着色促進に必要な光量 $5.1 \mathrm{MJ} \cdot \mathrm{m}^{-2} \cdot \mathrm{day}^{-1}$ を人工照明で補強する指標に決定した。

終りにあたって, 日射量の算定は, 大阪大学工学部建築工学科 の佐藤隆二助教授に, 内容のディスカッションは, 大阪工業大学 工学部電気工学科の前田成欣教授にご指導を受けました. 感謝の 意を表しま古。

\section{参 考 文 献}

（1）新村 出：広辞苑, p.123, p.1081, 岩波書店（昭48）.

(2) 長縄光延：やさしいイチジクづくク，pp.1-9, 52-53, 松尾 
印刷所（1987）。

（3）伊庭，福田，垣内，荒木：果実の成熟と貯蔵，pp.7, 8-9, 53-56，238，養賢堂 (1985).

（4）気象庁統計資料室：気象観測速報，1996.1 12.

（5）東京天文台：理科年表（1994）丸善（平 6).

（6）松浦邦男：建築環境工学 I, pp.28-30, 36, 朝倉書店 (昭 49).

（7）株本輝久：兵庫県農業総合センタ「特別研究報告書」, pp.9 -10 (1986-3).

(8) 柳原 等：中部電力研究資料, NO.85, pp.56-57 (1990-11).

（9）渡辺要編：建築計画原論 I, p129，丸善（昭37）。

(受付日1997年12月 3 日 / 採録日1998年 5 月 7 日)

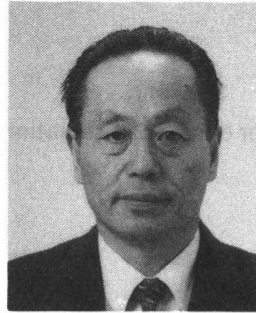

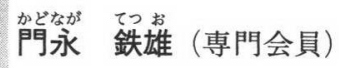

昭和 13 年 3 月 17 日生まれ。昭和 31 年 3 月米 子工業高等学校卒業, 同年松下電工株式会社 に入社. 昭和 41 年 3 月大阪工業大学短期大学 部電気科卒業. 屋内照明技術のコンサルティ ング業務を経て, 光放射応用技術の開発, 人材育成センター講師 などに従事. 平成 10 年 4 月松下電工秼式会社を定年退職。昭和 55 年技術士 (電気. 電子部門), 昭和 61 年より大阪工業大学短期大学 部非常勤講師 (電気工学・機械工学), 昭和 62 年より神戸大学工学 部電気電子系非常勤講師 電力応用 (照明工学)

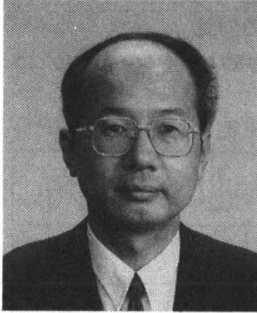

留防 信一 (専門会員)

松下電工株式会社 EC 総合企画部

昭和 22 年 10 月 22 日生まれ。昭和 45 年 3 月大 阪市立大学工学部電気工学科卒業, 同年松下 電工株式会社に入社. 現在に至る. 屋内照明 設計技術の開発を経て, 植物育成・害虫防除への光放射応用の研 究開発, UV 殺菌の研究開発などに従事. 平成 7 年技術士 (電気. 電子部門), 一般計量士 (平成 5 年), 植物工場学会会員, 日本技 術士会会員。

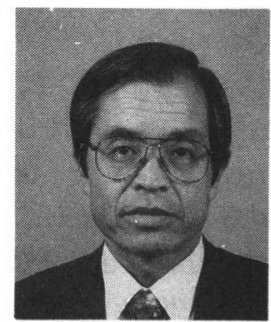

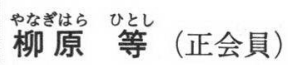

中部電力株式会社名古屋支店営業部

昭和 20 年 7 月 10 日生まれ. 昭和 39 年愛媛県 立松山工業高等学校卒業, 同年中部電力株式 会社に入社. 現在に至る. 主に, 農業電化関 係の研究業務, 施設園芸での電気加熱, 照明利用のほか電気応用 技術研究開発を経て, 産業技術コンサルティング, 蓄熱空調普及 開発業務に従事. 